\title{
The rise of digital authoritarianism: Evolving threats to media and Internet freedoms in Pakistan
}

\section{Sadia Jamil ${ }^{1}$}

Khalifa University of Science \& Technology, UAE

To cite this article: Jamil, S. (2021). The rise of digital authoritarianism: Evolving threats to media and Internet freedoms in Pakistan. World of Media. Journal of Russian Media and Journalism Studies 3. DOI: 10.30547/worldofmedia.3.2021.1

\begin{abstract}
Digital authoritarianism poses increasing challenges within both autocratic and democratic regimes. The evolving mechanisms of digital authoritarianism surpass national boundaries. Over the past decade they have advanced the interests of authoritarian states to undermine the freedoms of media and the Internet. In competitive authoritarian regimes, like Pakistan, digital authoritarianism has paved its way under democratic disguise. Reporters Without Borders' World Press Freedom Index 2020 indicates that the country ranks at 145 out of total 178 countries. Moreover, Freedom House's Freedom on the Net 2020 survey reveals Pakistan among the worst ten countries in terms of Internet and digital media freedoms. Considering these facts, hence this study examines digital authoritarianism in the journalistic context. It explores evolving threats to media and internet freedoms due to the increasing authoritarian practices of Pakistan's state authorities in digital realm. This is significant so as to unpack how the country's authorities restrain media and Internet freedoms in the digital age. To achieve this aim, this study uses the qualitative method of online interviews and presents findings thematically.
\end{abstract}

\section{Keywords}

Digital authoritarianism, media freedom, Internet freedom, competitive authoritarian regime.

\section{${ }^{1}$ Corresponding author:}

Sadia Jamil, Khalifa University of Science \& Technology, Near Home WTC AUH, Airport Road, Masdar City, Abu Dhabi, UAE.

Email: sadia.jamil@ymail.com 


\section{Introduction}

The proliferation of information and communication technologies (ICTs) and the fast-paced digitalization has opened up a world of opportunities for the public's empowerment and information exchange. Particularly, developments in digital media, are important because they are becoming a bedrock of contemporary information societies and journalism. The advantages of digital media, especially the use of the Internet, is often heralded in terms of better news productivity, swift dissemination, an increased public's engagement, political and social mobilization (Gambarato \& Alzamora, 2018; Jamil \& Appiah-Adjei, 2019). The Internet is indispensable to contemporary journalism, particularly investigative and cross-border journalism networks, which depend on information exchange across and to deliver important information to the public in times of crisis such as the COVID-19 pandemic. Notwithstanding positive implications, the proliferation of the Internet and fast-paced digitalization have also created many threats to the freedoms of media and the Internet. Journalists and news media organizations are now faced with digital authoritarianism, which is redefining threats to media freedom in many parts of the world. Repressive actions, such as the governments' online censorship, use of digital tools to monitor journalists and their sources, is widespread in democratic and authoritarian regimes both.

Digital authoritarianism is emerging as an overlying challenge within autocracies and democracies (Jamil \& Muschert, 2020). However, authoritarian states demonstrate an increased interest in using digital tools and techniques to restrain fundamental human rights and to undermine the freedom of media. Hitherto, 'cohort of countries is moving toward digital authoritarianism by embracing extensive censorship and automated surveillance systems' (Shabaz, 2018). Authoritarian governments, thus around the world, are using technologies, such as artificial intelligence, to control journalists' work and restrain media and Internet freedoms. 'The term digital authoritarianism has unfortunately now entered our lexicon' (Matthews \& Tsagaroulis, 2020).

In the case of Pakistan, the country can be described as a competitive authoritarian state, where democratic norms are quite often abused and media freedom is attacked through various mechanisms. Therefore, the state-media relationship in Pakistan, has never been friendly and the state has remained authoritative to control news media and journalists using different tactics (Akhtar \& Pratt, 2017; Jamil, 2015; Mezzera \& Sial, 2010; Parveen \& Nawaz, 2018). With the advent of Internet and the growth of ICTs in Pakistan, now 
the Pakistani journalists use digital platforms to report on issues. Evidently, now journalists' reporting can reach-out quicker and to a broader audience than before in Pakistan. Unfortunately, they are confronted with new forms of the government's authoritarian practices, such as the Internet and television channels' transmissions blockages, online threats and content censorship, imposition of stringent laws including the Prevention for Electronic Crimes Act (2016) and the Investigation for Fair Trial Act (2013), and digital surveillance of media professionals (Jamil, 2021a). These authoritarian practices have drastically affected the state of media freedom in Pakistan, and the country ranks at 145 out of total 178 countries in the Reporters without borders' World Press Freedom Index 2020 (Reporters without borders, 2020). 'Globally, Pakistan is among the worst ten countries in terms of Internet and digital media freedom' (Freedom House, 2020; Jahangir, 2019).

Reports by international organizations, evaluating media freedom and journalists' protection, do regularly highlight the declining state of media and Internet freedoms in Pakistan (Freedom House, 2020; Reporters without borders, 2020). Likewise, there are a number of recent and past studies that have addressed journalism practice and media freedom in Pakistan (Akhtar \& Pratt, 2017; Dickinson \& Memon, 2012; Mezzera \& Sial, 2010; Pintak \& Nazir, 2013); the state-media relationship in the country (Hussain, 2020); the state of press freedom (Jamil, 2015; Siraj, 2009); journalists' freedom and safety (Aslam, 2015; Jamil, 2020a); freedom of expression, press freedom and self-censorship (Nadadur, 2007; Park-Ozee, 2019; Parveen \& Nawaz, 2018); journalists' digital surveillance (Jamil, 2021a). More recently, Wagner (2017) offers an overview of the Internet shutdowns in Pakistan. This is an important study given it focuses on the state's authoritarian practices to attack the Internet freedom. While these prior studies are significant, yet no research has been carried out in the journalistic context to unpack the ways state exercises digital authoritarianism in Pakistan, and how it poses threats to media and Internet freedoms in the country. Therefore, drawing on the framework of competitive authoritarianism, this study aims to fill this gap in the literature. The article starts with the review of literature into the concepts of authoritarianism and digital authoritarianism, and the state of media and Internet freedoms in Pakistan. Next, the article explains competitive authoritarianism as the framework of this study. The article then goes on articulating the methodology and findings of the study. Lastly, it offers some recommendations to combat the rising digital authoritarianism in Pakistan. 


\section{Literature review \\ Understanding authoritarianism and digital authoritarianism}

Scholarship suggest that authoritarianism has different conceptual aspects. Political scientists describe it as a regime that does not hold regular, free and impartial elections. 'The presence or absence of free and fair elections is considered as the primary touchstone of whether a state is authoritarian or democratic' (Glasius, 2018). On the contrary political psychologists, do not focus on the regime type, rather they consider the personalities of power holders that are 'characterized by a desire for order and hierarchy and a fear of outsiders' (Glasius, 2018). In many democratic regimes, authoritarianism is a practice of ruling authorities that manifests itself in form of their authoritarian values and acts to influence the electoral process and to restrain the fundamental human rights and the freedom of media (Levitsky \& Way, 2010). This implies that democracy is not all about the presence of fair elections, it demands respect and protection for rights to freedom of expression, access to information and freedom of association. Therefore, authoritarianism is not just a regime type that is characterized by the state's failure to hold free elections, rather it is a practice as well that manifests itself in ruling authorities' failure to respect fundamental freedoms and rights (Hadenius \& Teorell, 2007).

Technological advancements have empowered the masses to raise their voices for their fundamental rights and have facilitated the success of activists' movements in many parts of the world. Opposition groups, in uprisings such as the Arab Spring, have notably used social media to organize their activities for strengthening democracy. Past studies have also suggested that an increase in the Internet adoption's rates is linked with both transitions to democracy and better levels of democracy, and hence improvements in respect for human rights. Technology can have a negative impact on human rights, such as rights to freedom of expression and access to information. For instance, technological advancements empower authoritarian governments by enabling 'preventive repression', which is often the rst and most important line of defense for authoritarians, hence allowing them to practice digital authoritarianism through using technological tools for preventive repression and exploitation of human rights (Ritter \& Conrad, 2016). Dragu \& Przeworski (2019) suggest: 'Preventive repression as the set of activities governments use to reduce the risk that opposition groups threaten governments' power, including opposition e orts to mobilize and organize public dissent. Preventive repression can include a wide range of tactics aimed at identifying, monitoring, and tracking potential regime opponents so as to neutralize them before they pose any real threat to the government' (Dragu \& Przeworski, 2019, cited in Dragu \& Lupu, 2020). 
In recent times, for instance, authoritarian governments have adopted new techniques to practice digital authoritarianism, which is 'the use of digital information technology by authoritarian regimes to surveil, repress, and manipulate domestic and foreign populations' (Polyakova \& Meserole). Digital authoritarianism mostly includes techniques, such as: Internet censorship ${ }^{2}$; online harassment; cyber-attacks; Internet shutdowns ${ }^{3}$; targeted persecution against online users; the use of voice recognition to scan mobile networks, GPS for tracking publics' movement using GPS, digital surveillance of public's electronic communication on e-mail, wats app and social media sites (Reuters \& Szakonyi, 2015). These techniques do not only affect people's Internet freedom, but it does affect journalists' work and the freedom of media more broadly.

\section{News media ecology and the state of media freedom in Pakistan}

Pakistan's linguistically diverse news media is very vibrant in South Asia. There is a cross-media ownership and there is a dominance of six media groups in

${ }^{2}$ Wagner (2018) highlight the generations of internet censorship. 'The first generation focused on "filtering systems at the backbone of the country's Internet $<\ldots>$ represents the first generation of Internet control techniques' (Deibert \& Rohozinski, 2010a). The 'second-generation controls aim to create a legal and normative environment and technical capabilities that enable state actors to deny access to information resources as and when needed' (Deibert \& Rohozinski, 2010b). The 'key characteristic of third-generation controls is that the focus is less on denying access than successfully competing with potential threats through effective counter-information campaigns that overwhelm, discredit, or demoralize opponents' (Deibert \& Rohozinski, 2010b). The 'fourth phase <...> we call "access contested". Although the central characteristics of the previous phases remain relevant, the key notion of this phase $\langle\ldots\rangle$ is that the contest over access has burst into the open' (Deibert et al., 2011).

${ }^{3}$ Wagner (2018) suggests that the internet shutdowns 'differ from Internet censorship in several different ways: 1) Internet shutdowns do not discriminate regarding content. Instead, they block all content and do not attempt to discriminate what kind of content they block, whereas Internet censorship targets specific items or types of content; 2) Internet shutdowns encompass all forms of digital communication. Although Internet censorship only affects Internet communications, Internet shutdowns typically also directly affect mobile phone and sometimes even other forms of telephony. This makes the scope of communications affected significantly broader; 3) Internet shutdowns have different effects than Internet censorship, as they have an entirely different scope and the focus of the measure is different. Although in the context of Internet censorship some digital communication is still possible, and some access to uncensored content exists, this is not the case during Internet shutdowns. As a result, communicative ruptures can only meaningfully be discussed in the context of Internet shutdowns and not in the context of Internet censorship; 4) Internet shutdowns have a different intent than does Internet censorship, as their focus is not on a specific piece of content but rather on the act of communication itself'. 
the country: The Dawn Group, the Jang Group, the Express Group, the ARY Group, Dunya Group, and the HUM TV Group (Jamil, 2021b). According to the statistics of Pakistan Bureau of Statistics (PBS), 'the number of newspapers and periodicals in the country stood at 539 in 2016. As of late 2017, 89 satellite TV licenses have been issued by Pakistan Electronic Media Regulatory Authority' (Najam, 2019, cited in Jamil, 2020b). Most of the news channels broadcasts news in Urdu language. However, there are many channels that broadcasts news in ethnic/or provincial languages, such as Pashtu, Sindhi, Balochi and Punjabi (Jamil, 2020c).

As far as the state-media relationship is concerned, it has been not so amiable in Pakistan and the state remains powerful to repress media and journalists through: press laws (such as criminal libel laws (Pakistan Penal Code, 1860), Official Secrecy Act (1923), Blasphemy laws (Pakistan Penal Code, 1860); takeover of media outlets (such as Progressive Press Limited); the establishment of government's mouth-piece news outlets (such as the National Press Trust); controlling of news agencies (such as the Associated Press of Pakistan); restrictive allocation of advertising quota to newspapers; banning of transmission and cancellation of licenses of television news channels; and distribution of awards to journalists that report in favor of the government (Jamil, 2015; Mezzera \& Sial, 2010; Siraj, 2009).

Unfortunately, the fear and the power of government and intelligence agencies override media freedom and its watchdog role in Pakistan (EllisPetersen \& Baloch, 2019; Sarfraz, 2020). The promulgation of laws, such as PECA law (Prevention of Electronic Crimes Act, 2016) and the Investigation for Fair Trial Act (2013), has further increased the journalists' concerns about their digital surveillance. Pakistan's PECA law (2016) now empowers Pakistan Telecommunication Authority to surveil and block anything that is deemed as offensive to any person, religion and against the national interest of the country. Investigation to Fair Trial Act (2013) empowers the state authorities to monitor journalists and citizens of Pakistan on the pretext of fair trial (Jamil, 2020a). These laws retrain the freedom of media given not only they affect journalists' work, but also they are vague in explanations of what exactly considered as objectionable and against the national interest of Pakistan.

\section{The state of Internet freedom in Pakistan}

The Internet penetration has considerably increased in Pakistan during the past decade (Jamil, 2020d). The country's government has been able to successfully provide the Internet's access to remote areas in recent years, despite the Pakistani 
citizens and residents still confront the challenge of digital divide. 'Pakistan is the fourth-largest country in Asia - behind Indonesia, India and China' (Hussain, 2017). Yet, a large proportion of the Pakistani people still cannot access and use the Internet and as the penetration remains worryingly low. The Internet access in Pakistan stands at 'around 35 percent, with 78 million broadband and 76 million mobile Internet (3/4G) connections' (The Economist, 2020; Jamil, 2019).

One of the major challenges is the Internet freedom in Pakistan, in addition to the country's existing digital divide. 'Internet freedom includes concepts such as digital rights, freedom of access to information, and net neutrality' (Alais, 2020). Digital rights are basically same fundamental human rights that exist in the offline world, as well as in the online world. This means acknowledging fundamental human rights (such as rights to freedom of expression, access to information, reputation and privacy) in the cyberspace (Nitsche \& Hairsine, 2016). Therefore, the provision of digital rights is linked to the freedom of media. Journalists need rights to freedom of expression to express themselves freely online and to access the information using the Internet. Media organizations need freedom to run their news web-sites freely and to broadcast and publish news content online without any restrictions. Nevertheless, this is not the case of Pakistan. For instance, Pakistan's authorities often interrupt telecommunication services during protests, elections, and religious and national holidays, providing the reason of security concerns to the public (Jamil, 2020d). Now the country's authorities use PECA laws (Prevention of Electronic Crimes Act 2016) and the Investigation for Fair Trial Act (2013) to silence critical journalists for their online expression and commentaries.

Recently, the Pakistani government has passed a new set of laws that is aimed to control extremism, terrorism, online hate speech, incitement of violence and anti-state sentiments and the dissemination of fake news on social media platforms (such as Facebook and Twitter). Media professionals are now more concerned considering these laws would further strengthen digital censorship in Pakistan (Dawn, 2020). The 'Citizens protection (against online harm) rules, 2020' require Google, Facebook and Twitter to filter or remove social media posts that are considered objectionable by the government of Pakistan. The new set of laws empower the government to obtain data and information from the aforementioned companies (Shahzad, 2020). In addition to the introduction of new laws, Pakistan's Ministry of Information and Telecommunications requires social media companies to deploy their contact persons in the country, who would be obliged to report a National Coordinator, appointed by the country's Ministry of Information and Telecommunications (Chabba, 2020). 
Apart from stringent laws, the government's and intelligence agencies' surveillance and social media monitoring are key concerns of the Pakistani journalists (Bari, 2021). Ironically, to date, there are no adequate laws for online data protection and online free speech right in Pakistan. Therefore, journalists exercise self-censorship, when writing (either online or offline) on topics such as: religion, blasphemy, civil-military relations, separatist movements, and women's and other minority communities' rights (Azeem, 2019; Chaudry, 2018; Park-Ozee, 2019). Thus, it is evident that digital authoritarianism is on rise in its various forms in Pakistan. However, this study unpacks in detail how it poses threats to media and Internet freedoms in the country.

\section{Theoretical framework: Competitive authoritarianism}

Competitive authoritarianism can be defined as a 'hybrid political system' and 'one of the sub-types of non-democracies', which is 'characterized by the weak enforcement of formal rules' (Levitsky \& Way, 2010). Unlike authoritarian regimes, such hybrid political system is marked by regular elections, though these are not free and impartial. To control competition, official authorities continually breakup rules of democratic institutions (Levitsky \& Way, 2002), and they impose restraints on both 'political organization and political candidates' (Ottaway, 2003). Distinctly, in competitive authoritarian regimes, independent media exists but the freedom of media is quite often attacked. Therefore, it lacks institutions that hold power holders accountable and effective regulatory frameworks that protect journalists (Chaocon, 2009).

In view of the scholarly description of competitive authoritarianism, Pakistan can be considered as a competitive authoritarian regime where elections are basically a democratic disguise, the ruling or dominant political party earns almost all the seats, democratic norms are frequently abused, and journalists and media professionals are often attacked being critical of the government and the state institutions (Park-Ozee, 2019). Journalists face surveillance, which is at times life threatening to them. The ineffectiveness of institutional mechanisms to protect their rights to freedom, privacy and safety creates an imbalance of power-relationship between the state and journalists. The advent of technology has provided new ways to the Pakistani authorities to attack the freedom of media through digital surveillance of journalists, blockage of news web-sites, Internet shut down, restrictions on free speech on social media platforms and imposition of laws that pave the way for digital mass surveillance (Digital Rights Foundation, 2018). Thus, the rationale for using the framework of competitive authoritarianism is to investigate the ways digital authoritarianism is posing 
threats to media and Internet freedoms in Pakistan, which is governed by a democratic government, yet reflects a myriad of authoritarian practices of ruling authorities.

\section{Methodology \\ Research question, data collection method and sampling}

This study uses the qualitative method of online interview to explore a research question, namely: how digital authoritarianism poses threats to media and Internet freedoms in Pakistan? A total of 20 Pakistani male and female journalists (i.e., 10 males and 10 females) have been interviewed online using Zoom. Given the possible risks of interviewing journalists face-to-face and travel restrictions due to COVID-19 pandemic, the researcher has chosen to carry-out online interviews. Furthermore, interviewed journalists have been selected using purposive sampling (see Lavrakas, 2008). The rationale for using purposive sampling is to make sure the journalists' representation from Pakistan's mainstream Urdu and English languages' newspapers and television news channels both.

The male and female journalists, who have participated in this study, are of age ranging between 28 and 55 years, and they are full-time employee of Pakistan's mainstream Urdu and English languages' newspapers and television news channels. Journalists, who have been interviewed in this study, are full time employees of four leading English language's newspapers (Daily Dawn, Express Tribune, The Nation, and The News International); three leading Urdu language's newspapers (Daily Jang, Daily Express, and Nawa-e-Waqt); seven Urdu language's television news channels (Geo News, Express News, SAMAA News, ARY News, AAJ News, Dunya News, and Pakistan Television Corporation-PTVNews). Furthermore, all selected journalists in this study, are those who manage journalistic work for the news web-sites of their respective news organizations, apart from their work for traditional media (i.e., newspapers and television news channels). This means the selection of journalists with experience of online and offline journalism both. Internet is the need of every journalist these days to carry-out his/ or her routine work. However, the purpose of selecting the Pakistani journalists with experience of online journalism is to shed light on the state's digital authoritarian practices, based on their routine observation and experiences of online journalism.

\section{Data collection process}

The researcher has gathered the data of this study between 18th September, 2020 and 3rd November, 2020 through online interviews. Initially, the 
researcher had communicated to working journalists in Karachi through phone calls and e-mails using her personal contacts. There were some di culties during the data collection. Many contacted journalists could not give online interview due to their Internet connectivity issues as per the scheduled time, as well as because of their personal and professional problems. However, the researcher was able to complete 20 online interviews by the first week of November, 2020 . In this study, each journalist has been interviewed for around 50-60 minutes online and in English language, which is the official language of Pakistan. Subsequently, the interviews' transcripts have been transcribed and analyzed for themes. Journalists, in this study, have been interviewed online using Zoom.

All interviewed journalists have been asked questions using an interview guide, which lists key interview questions, for instance: what traditional ways of attacking media freedom have been used in Pakistan since its inception as an independent country? How have attacks on media freedom changed with the advent of technology? What tactics do state authorities use to control journalists' online work? How is Internet freedom curtailed by Pakistan's government? How do journalists view the impact of state's digital authoritarianism on media and Internet freedoms in the country? These are the key interview questions that have been asked to Pakistani journalists. However, based on journalists' responses, they have been asked follow-up interview questions.

\section{Challenges of online interviews}

Online interviews, as a data collection method, have advantages and disadvantages both. For example, the main plus point is that it helps the collection of data distantly, especially when it is difficult to conduct interviews in person during the pandemics. However, it has some limitations too. For instance, in countries like Pakistan, not every person has access to reliable Internet connection at home and there are other problems, such as frequent electricity load shedding and power failure. Therefore, for a number of journalists, the researcher had to repeatedly reschedule the online interview and four interviews have been conducted in two separate sessions due to Internet interruption at the interviewees' workplace. Despite technical issues, online interviews require extra effort and time to discuss the research topic and scope with interviewees. For this purpose, the researcher scheduled short Zoom meetings with 11 journalists, and discussed research project with rest of them on phone calls, which was expensive though. These issues can be exhausting for the researchers, who carry out data collection remotely. 


\section{Challenge of bias in qualitative research}

Bias usually refers to the influence of a researcher's individual opinions and thoughts that may distort the results of a study (Polit \& Beck, 2014). In qualitative research, the issue of bias is very common, and researchers often find it hard to justify the fairness and trustworthiness of their collected data (Thorne et al., 2016). A host of strategies can be used to avoid the occurrence of a researcher's bias in qualitative studies. In this study, the researcher used mainly two strategies: (i) the use of additional data sources to better understand the state of media and Internet freedoms in Pakistan, (ii) the maintenance of coding consistency and the use of secondary coder for fair interpretation of data.

To avoid individual bias, the researcher firstly reviewed past five years' reports by international and national organizations that regularly monitor violations against media and Internet freedoms such as reports by Freedom House, Reporters without borders, Committee to protect journalists (CPJ) and Digital rights foundations (Pakistan). In addition to reviewing reports by these organizations, the researcher also reviewed scholarly studies into media and Internet freedoms in Pakistan. However, the review of scholarly studies suggested the scarcity of national studies into this area.

Moreover, the researcher remotely worked together with a secondary coder, who is a $\mathrm{PhD}$ student in a local university in Karachi. The purpose of having a secondary coder was to ensure data coding consistency and the fair interpretation of coded data. The first round of data coding indicated subtle differences in coded themes primarily in terms of the phrasing of codes by the researcher and secondary coder. Subsequently, both coders discussed the coding of data in order to finalize the codes and themes for thematic analysis.

\section{Data ethics and analysis}

All interviewed journalists have been provided a project information sheet through e-mail that explains information about a research topic, types of interview questions, voluntary involvement in research project, anonymity of journalists' names and their access to research ndings once it is published. The project information sheet also explains the key terms in interview questions, such as digital authoritarianism, Internet freedom and digital rights. This was done to obtain journalists' responses with better clarity.

With the purpose of ensuring the privacy and safety of interviewees, all interviewed journalists have been quoted using numbers (ranging between 1 and 20). In addition, this study employs thematic analysis to analyze the interview data under sub-themes that have emerged inductively from the data, revealing threats to freedoms of media and the Internet in Pakistan. The sub-themes have 
been categorized according with the frequency or prevalence of keywords in the journalists' responses to the research question. The prevalence of sub-themes (i.e., indicated with p), corroborated with quantitative estimations, has been decided based on the number of journalists' responses in each sub-theme.

\section{Results and discussion Threats to media freedom due to digital authoritarianism in Pakistan}

Authoritarian governments, across the world, devote more time and resources on controlling and repressing dissent than on the well-being of their citizens. Pakistan is no different (Jelani, 2019). Authoritarian practices, such as election manipulation, media propaganda against opposition groups, censorship, financial incentives to journalists, legal actions against critical journalists and media organizations, all have been in common in Pakistan since decades (Akhtar \& Pratt, 2017). However, the situation of media freedom has turned apprehensive in the past couple of years that is manifested in Pakistan Federal Union of Journalists' call for nationwide campaign to combat censorship and protect the freedom of media. Saeed (2021), in his report for Arab News, writes: 'Journalists' complaints range from direct edicts to editors and producers not to air or publish news critical of the government or the military, the suppression of opposition political voices, pulling TV stations from transmission or newspapers from circulation and targeting the advertising revenue of dissenting media. Newspapers and news channels across the country have announced mass layoffs in recent months as advertising funding and revenues have dried up'.

Echoing the concerns of Pakistan Federal Union of Journalists (PFUJ), The News International reports: 'The council 'heavily criticized' the government for allowing and even forcing media regulators including Pakistan Electronic Media Regulatory Authority (PEMRA), Pakistan Press Council (PCP), and Pakistan Telecom Authority (PTA) to exceed their mandates and use coercive means to hound journalists and pressurize media houses to crush freedom of expression and professional journalism'. (The News, 2021)

While these reports indicate an increased control of state's institutions on journalists' work and the operation of free media, this study reveals a rampant rise in digital authoritarianism in Pakistan. All interviewed journalists suggest that the freedom of media has declined because of the abuse of their digital rights by the Pakistani authorities. For instance, male producer of a private television news channels, states:

We do have constitutional rights to freedom of expression and access to information. Articles 19 and 19 (A) of the Constitution of Pakistan (1973) 
guarantee rights to freedom of expression and access to information, but with certain restrictions. However, these rights are not practiced in reality. Now with the emergence of cyberspace, journalists are more concerned about their digital rights, such as online free speech, access to information, online data and privacy protection. (Interviewee number 3 )

When talking about the state-media relationship and the declining media freedom in Pakistan, a senior journalist of a private television news channel in Karachi, highlights:

The state-media relationships have always been turbulent in Pakistan since its inception as an independent country. However, now digital surveillance and online censorship have emerged as an advanced forms of the government's media control in Pakistan. I have stopped writing articles for the news web-site of an Urdu-language's newspaper. I was told by the editor that he had received pressure calls from the government's officials to edit the critique on government in my articles. (Interviewee number 2)

The political legacy of Pakistan can be viewed as one of the key defining aspects of the state-media relationship in Pakistan. For instance, an interviewee from an English-language's newspaper underlines, 'we have a few dominant political parties that rule the country alternatively. Then the military has a huge influence on the Pakistani politics. This creates barriers to facilitate the free operation of media as per the constitutional rights' (Interviewee number 16).

Interviewees' responses reveal three major threats to media freedom due to the state's authoritarian practices in the digital realm. Table 1, below, explains major threats to media and Internet freedoms due to digital authoritarianism in Pakistan.

Table 1

Threats to media freedom due to digital authoritarianism in Pakistan

\begin{tabular}{|c|c|}
\hline Sub-themes & $\begin{array}{c}\text { Number of male } \\
\text { interviewees ( } \mathbf{n}=20)\end{array}$ \\
\hline $\begin{array}{c}\text { Sub-theme 1: } \\
\text { Digital surveillance of journalists }(\mathrm{p}=20)\end{array}$ & 20 out of 20 \\
\hline $\begin{array}{c}\text { Sub-theme 2: Digital risks } \\
\text { (cyberattacks, threats to privacy) }(\mathrm{p}=13)\end{array}$ & 13 out of 20 \\
\hline Sub-theme 3: State's propagation of disinformation ( $\mathrm{p}=4)$ & 4 out of 20 \\
\hline
\end{tabular}


Digital technologies permit new forms of digital surveillance and data collection that threaten journalists' right to privacy, as well as pose risks to their safety. The majority of interviewed journalists highlight that surveillance of journalists' digital communications (such as through mobile phones, e-mails, wats app and social media sites), is carried out by the intelligence and law enforcement agencies in Pakistan (See Table 1, Sub-theme 1). Consequently, journalists are unable to perform their routine work safely and freely and that has implications for the freedom of media in Pakistan. In this regard, director news of a private television news channel, suggests:

We cannot expect a free media in Pakistan with the culture of surveillance. Now government and intelligence agencies do not have to surveil a journalist physically. Technology has made their task of journalists' monitoring very easy. Journalists' phone calls, e-mails, wats app communication and social media posts, all are monitored by the state authorities. Particularly journalists, who report on national security, politics and crime, are most affected by digital surveillance. And by the way, female journalists are not exempted if they are vocal or critical about the government, any political party and intelligence agencies. (Interviewee number 9)

Notably, journalists' surveillance is not mere a common practice in authoritarian and competitive authoritarian regimes - such as Pakistan. This is now pervasive in the Western democracies too, turning them into 'surveillance societies' (Mills, 2019). For instance, in the United States, this is happening after Edward Snowden's revelation about a surveillance programme, PRISM, developed by the National Security Agency (NSA). This surveillance programme permits NSA to keep a record of journalists' communications through emails, telephone and social media; their personal and professional documents stored in digital devices (such as mobile phone and laptop); and other data repossessed from global Internet companies, including Google, Apple, Microsoft and Facebook (Bigo 2014; Lashmar, 2018; Lyon, 2015; Stein 2013). Digital surveillance of journalists is also common in other Western countries as well, such as Australia and the United Kingdom (Lowenthal 2015; Mills, 2019). In this way, digital authoritarianism is making its roots in the Western democracies as well. Nevertheless, the difficulty for the Pakistani journalists is related to the fatal safety risks that they experience due to constant and covert digital surveillance, which does affect their work and media freedom more broadly. For example, a female political reporter says: 
Digital surveillance is no more unique to authoritarian regimes given it is being practiced by the Western democratic governments too. But we must understand the nature of democracy in Pakistan. We do have a democratic government, which uses every mechanism to curb the freedom of media and to pose risk to journalists' lives. Technology has basically made it easy for the government to use different digital tools to buttress their authoritarian practices. (Interviewee number 19)

Another female news producer of a private television news channel mentions:

Media is controlled through laws, restricted subsidies to newspapers and allocation of government's advertisements, pressure and warning calls. But these controlling tactics do not result in life threat to journalists and their sources. Digital surveillance is risky given it is extremely easy to locate a journalist and his/or her sources. Personally, I do editing tasks for online news web-site of our television news channel, in addition to field reporting. I avoid writing any opinion piece because I do not want to come under the limelight being critical of some government's recent actions against the news media (Interviewee number 17)

It is important to note that journalists frequently rely on whistleblowers and other confidential sources to collect and report information in the public interest, yet digital surveillance of journalists is risky for their sources' physical safety and privacy both across Pakistan (See also Lashmar, 2018). With regard to this, a male political correspondent of a private television news channel, mentions:

Location tracking is so common now due to advancements in technology. The Pakistani journalists need to be really careful in their digital communications given they are operating in a surveillance state. It is not only risky for them, but also for their sources too. Then they do face cyberattacks in forms of email and social media accounts' hacking and online threats. (Interviewee number 4)

Unpacking risks to journalists' sources due to digital surveillance, Interviewee number 4 further says:

Let me share a recent incident, which has occurred with my male and female colleagues, and who work for two leading English-language newspapers. One of my male colleagues, who is based in Peshawar, has faced a car accident recently 
in late August 2020. He left his home for a market and he was hit by a Van. My colleague reports actively on Pashtun Tahafuz Movement (PTM) and he has been receiving constant death threats since last one year. He shares that his sources in Federally Administered Tribal Areas (FATA) are missing and he is unable to contact with them. (Interviewee number 4)

The fast-evolving digital news media landscape offers great opportunities for the Pakistani journalists to investigate and report on information in the public interest, but it also poses specific challenges regarding the privacy and safety of journalistic sources due to an increased digital surveillance and online safety risks. This study suggests that an environment of fear has created for the Pakistani journalists and risks to their mental well-being have heightened due to the fear of digital surveillance and risks. 'Now the state authorities are empowered to inject their fear among journalists through their digital surveillance. The sense of being monitored actually kills journalists mentally', states a female interviewee (Interviewee number 20). This implies that creating fear among journalists is one of the state authorities' motives of carrying out digital surveillance, in addition to keeping an eye on their activities in Pakistan. The matter of concern is journalists are not able to fully tackle with these challenges. For instance, according to an interviewee:

Four journalists have been murdered in 2020 in Pakistan. Three of them, including Aziz Menon, Javedullah Khan and Anwar Jan have lost their lives being critical reporters. Mostly journalists practice self-censorship either in their reports or on social media communication to avoid fatal consequences. They do not know what else they can do to mitigate risks associated with digital surveillance. (Interviewee number 6).

These findings suggest the necessity of journalists' training to deal with digital risks in Pakistan. The practice of self-censorship is certainly not a solution to combat digital risks. 'We are compelled to exercise caution in our social media communications, especially wats app and Facebook', says a male interviewee (Interviewee number 2). Markedly, political and religious communications on social media demand a very high level of caution by the Pakistani journalists, thus limiting their use of new media platforms for sharing journalistic commentaries and reports. For example, a male interviewee highlights:

Our religious speech is restricted, either online or offline, because of blasphemy laws. And indeed no one would like to face violent public reaction. In 
terms of political speech, particularly on social media (including Facebook and Twitter), some journalists are very vocal regardless of consequences. A majority practice self-censorship when posting critical posts about the government, political parties and the army. (Interviewee number 4)

This study further finds that digital authoritarianism has evolved in many other ways to affect the freedom of media and its integrity as an institution in Pakistan. For instance, some male journalists reveal that state authorities attempt to jeopardize the legitimacy of media as the watchdog of society through dissemination of fake news and disinformation on the Internet. 'There are many news web-sites that are paid by the government and intelligence agencies to disseminate fake news and disinformation against opposition groups. Then social media has become a fertile ground for the dissemination of fake news and disinformation', says a female news anchor of a private television news channel (Interviewee number 16). Similarly, another interviewed male journalist from an English-language newspaper, says that 'the government and local political parties disseminate disinformation online for the sake of their vested interests. You cannot trust on information available on the social media' (Interviewee number 6). Furthermore, interviewed journalists reveal the ascendance of informational flooding, which is a subtler method to impinge the legitimacy of free media in Pakistan. For instance, a female interviewee suggests:

Pakistan's news media has recently confronted drastically with informational flooding - especially during the country's 2018 election and COVID-19 pandemic. Now the state is not just relying on censorship, but it controls the information flow through Internet shutdown and online censorship, as well as by facilitating the flow of fake news and disinformation, which is a good way to distract the public's attention and keep them engaged in absurd debates. The Pakistani journalists have to combat with such indirect attacks on the freedom of media and the government control over Internet freedom both. (Interviewee number 23)

'Flooding assumes that censorship will not always succeed, and in fact might be counterproductive. It therefore does not bear the clear stamp of autocracy like traditional methods of control' (Gunitsky, 2020). Flooding, in forms of false news and disinformation on social media, is thus becoming a common practice of the state's authorities in Pakistan (Jamil \& Appiah-Adjei, 2020). Consequently, social media have emerged as an untrusted source of news and information in Pakistan. For instance, a recent study conducted by Digital Rights 
Foundation (2020), reveals that almost 88 percent of surveyed journalists find social media as the 'least worthy source of information'. Interestingly, regardless of this fact, most journalists neither verify information available on social media nor they check the source of information (Digital rights foundation, 2020). These findings suggest that the state's authoritarian practices are not entirely changing in Pakistan, rather the nature of controlling mechanisms are further expanding with new forms of digital repression, suggesting the transformations in state's actions to curb media freedom within a competitive authoritarian regime. The next section further addresses the ways Pakistan's authorities exercise authoritarian practices to curb the Internet freedom in the country.

\section{Threats to Internet freedom due to digital authoritarianism}

In the past decade, global Internet freedom has continuously declined as particularly the social media ever more being used by governments (either democratic, or authoritarian or competitive authoritarian) around the world as a 'conduit for mass surveillance and electoral manipulation'. Digital platforms have now emerged as 'a new battle ground for democracy' (Belson, 2019), and the world witnesses a steady rise in digital authoritarianism. This study unpacks that Pakistan's state authorities practice digital authoritarianism in three ways to control the Internet freedom in the country. Table 2, below, explains threats to Internet freedom due to digital authoritarianism in Pakistan.

Table 2

Threats to Internet freedom due to digital authoritarianism in Pakistan

\begin{tabular}{|c|c|}
\hline Sub-themes & $\begin{array}{c}\text { Number of male interviewees } \\
(\mathrm{n}=\mathbf{2 0})\end{array}$ \\
\hline $\begin{array}{c}\text { Sub-theme } 1: \\
\text { Social media laws and restriction on freedom of } \\
\text { expression online }(\mathrm{p}=18)\end{array}$ & 18 out of 12 \\
\hline $\begin{array}{c}\text { Sub-theme } 2: \\
\text { Internet shutdown }(\mathrm{p}=10)\end{array}$ & 10 out of 20 \\
\hline $\begin{array}{c}\text { Sub-theme } 3: \\
\text { Content blockage on the Internet }(\mathrm{p}=10)\end{array}$ & 10 out of 20 \\
\hline
\end{tabular}

A majority of male and female journalists, in this study, express their concerns about Pakistan's newly introduced Internet rules in 2020 and social media laws. For example, a female political reporter from a private television news channel, expresses her concern in a way: 
Now you see the promulgation of Pakistan's new Internet laws in the beginning of 2020. These are not just threat for Internet freedom, but indirectly it impinges on media freedom as well given it restricts journalists' and media organizations' freedom to post freely any critical posts on their social media sites. (Interviewee number 19)

Pakistan's new Internet rules would not only pose chilling effect to the journalists' right to freedom of expression, but also it would foster ambiguity of dos and don'ts among them. Though the new Internet rules do define the parameters of objectionable online content, it does not explicitly explain what is against the national interest of Pakistan? This would make journalistic job more difficult. The new Internet rules also directly affect the operation of social media companies in the country, including Google and Facebook. Earlier, the Internet shutdown used to occur for the public and in specific geographical areas, such as in Federally Administered Tribal Areas, Baluchistan and Khyber Pakhtunkhwa provinces (Wagner, 2018). In urban cities, Internet shutdown happens usually during specific religious dates, such as $12^{\text {th }}$ Rabi-ul-Awal (i.e., the birth of Holy Prophet peace be upon him) and $10^{\text {th }}$ Moharram (i.e., the martyr day of Imam Hussain). The new Internet rules do not aim for shutdown, rather it has increased the state's power to practice Internet censorship. For instance, a male interviewee from the state-owned television news channels, states:

Early in 2020, Pakistan's government has introduced 'Citizens protection (against online harm) rules', which empowers Pakistan Telecommunication Authority to block or to remove any content that is considered as objectionable by state authorities. Though these rules define objectionable content (such as hate speech online, derogatory content towards Islam or any religion, speech against national security and national interest). But term, like national interest, is too broad. And it can be interpreted by different ruling governments differently. This allows a good pretext for carrying out online censorship. (Interviewee number 7)

Findings suggest that journalists, either working in state-owned media organization or in private news media organizations both, are apprehensive about the new Internet rules in Pakistan. They view that these rules would not only affect working journalists for their routine work, but these would affect common masses as well. Interestingly, a few female journalists and a male journalist from Urdu-language newspapers, view Pakistan's Internet rules as 
necessary for maintaining religious and cultural values of the country (See Table 2, Sub-theme 1). For example, a female journalist from a leading Urdulanguage's newspaper emphasizes:

I don't see any problem in new Internet laws of Pakistan. You look at our society. People have simply forgotten their culture and values. Internet web-sites need to be regulated as per the Islamic laws and considering what is appropriate in our society. (Interviewee number 12)

Another female interviewee from an Urdu-language's newspaper asserts:

People randomly posts content that deemed as indecent or at times can impinge the national interest of Pakistan. Particularly, political content that enhances ethnic divide in Pakistan and aggravate political relations among provinces. Religiously, Pakistan is a Muslim country and government is absolutely correct to monitor blasphemous content online. (Interviewee number 15)

Unregulated political speech, on the Internet and specifically social media, has potential to move the public into segmented 'echo chambers', increasing ethnic differences and political conflict in Pakistan. In many other Asian countries, Internet has proven to be a fertile ground for disinformation, hate speech and propaganda in the past couple of years. For example, a report by Freedom House released in 2018, suggests: 'Over the past 12 months in Bangladesh, India, Sri Lanka, and Myanmar, false rumors and hateful propaganda that were spread online incited jarring outbreaks of violence against ethnic and religious minorities. Such rifts often serve the interests of antidemocratic forces in society, the government, or hostile foreign states, which have actively encouraged them through content manipulation'. (Shahbaz, 2018)

Issues, such as online hate speech and racism, political propaganda, incitement of violence and terrorism, offence to religion, require governments to develop regulatory frameworks for the Internet and social media. The author argues that regulating Internet freedom in competitive authoritarian countries, like Pakistan, is not transparent because state authorities do have several mechanisms to attack media and Internet freedoms under democratic disguise. Pakistan is a pre-dominantly a Muslim country, which already has laws that restrict blasphemous speech (e.g., Pakistan Penal Code, 1860; Article 19 of the Constitution of Pakistan, 1973); and defamatory speech (Criminal libels laws of Pakistan Penal Code, 1860; Defamation Ordinance, 2002). The new 
set of regulations, including 'Citizens protection (against online harm) rules, 2020', empowers Pakistan Telecommunication Authority (PTA) for 'removal and blocking' of digital content that 'harms, intimidates or excites disaffection' towards the government or poses a threat to the 'integrity, security and defence of Pakistan' (Shahzad, 2020). Besides, Pakistan's new Internet rules requires service providers and social media companies (such as Facebook, Twitter and YouTube) to ensure effective filtration to avoid dissemination of content that is considered pornographic, offensive to Islam or any other religion, incite hatred and violence, foster terrorism and harmful for the country's national security. In the case of non-compliance, social media companies and service providers may face fines up to 500 million rupees ( $\$ 3.14$ million). Unlike a few journalists, as quoted above, many interviewed journalists, thus express their concerns regarding social media laws and restrictions on online free speech in Pakistan. For example, a senior male journalist of an English-language newspaper, expresses his concerns:

The new Internet rules are apprehensive. They do not just affect public in general. These rules provide an unprecedented censorship powers to Pakistan Telecommunication Authority. The Pakistani news media is already facing attacks on its freedom through various other ways, particularly through constant journalists' surveillance, life threats, restrictive allocations of government's advertisements and pressure calls. With such massive restrictions for free speech on social media and other Internet sites, we can only expect further damage to the freedom of media, especially digital media, such as online news web-sites and broadcasters. (Interviewee number 6)

Despite the issue of Internet and social media laws, Pakistan's government at times restricts Internet access or limit the provision of Internet services in certain areas of the country that serves to curb the public's right to freedom of expression and access to information (Jamil, 2020e, 2020f). One of the male interviewed journalists, in this study, reveals:

Internet shutdown in certain areas, such as Balochistan, North and South Waziristan and Federally Administered Tribal Areas (FATA), is a routine practice in Pakistan. Then the government shuts Internet on religious events such as $12^{\text {th }}$ Rabi-ul-Awal (i.e., the birth of Holy Prophet, peace be upon him) and during Moharram processions in the first Islamic month. Though the government and law enforcement agencies offer justification of Internet shutdown to the public, 
saying it is to prevent any terrorist activity. However, it does not make sense to me. Now you imagine a journalist operating in a situation when mobile and Internet services are suspended. (Interviewee number 10)

Markedly, the Internet freedom has declined during 2020 due to the state authorities' increased blocking of political, social, and cultural web-sites and undeclared policy of connectivity restrictions in Pakistan. According to a female news producer of the state-owned television news channel:

Cyberspace space for public and freedom of expression in Pakistan has minimized, while digital surveillance and stringency of laws have increased. Many news web-sites experience blockages frequently. Threats to media freedom have transformed in Pakistan. Now it has taken forms of online censorship and digital surveillance. Given there is only one state-owned broadcaster, journalists working in private news media organizations, feel the heat of digital authoritarianism more. (Interviewee number 13)

This study manifests that the Internet shutdown, web-sites' blockage and online content removal have not just affected the Internet freedom in Pakistan, but it is affecting the freedom of media as well. 'As now growing portions of journalistic activity take place on the Internet, Pakistan is certainly not a safer place for those expressing critical opinions on the Internet. They may face judicial trials, attacks and threats', for instance says a female interviewed journalist from an Urdu-language newspaper (Interviewee number 14). Thus, the Internet is now a powerful tool for strengthening and legitimizing the power of competitive authoritarian rule in Pakistan.

\section{Conclusion}

Drawing on the framework of competitive authoritarianism, this study suggests that both old and new threats exist when journalists decide to be critical of the government and intelligence agencies in Pakistan. The old threats to media freedom, in forms of violence, stringent laws, physical surveillance, arbitrary detentions and life threats, are pervasive in the country. What has changed is the government's and intelligence agencies' use of digital tools to intervene journalists' work and the freedom of media through digital surveillance, online threats and cyberattacks. This study suggests that the competitive authoritarian milieu of Pakistan is evolving given now state employs different tactics to curb the freedoms of media and the Internet, thereby to strengthen its power, control and fear over journalists. The most 
notable tactic is to create the fear of surveillance and digital risks, and to facilitate information flooding, as suggested by the interviewed journalists in this study. While using the traditional methods of repression, Pakistan's state authorities make it more difficult for journalists to access information through Internet shutdown and online censorship. In addition, digital autocrats use information flooding and fake social media accounts for digital propaganda that help the government to amplify narratives and to create polarization among journalists, as well as to control information received by the public. Administering the national infrastructure and legislation of telecommunication, now Pakistan's government successfully block journalists' and the public's access to specic Internet content, and monitor and persecute dissident online authors (Jamil, 2020e).

As aforementioned, now an increasing portion of journalistic work involves the use of Internet. This necessities Pakistan's government to acknowledge the importance of digital rights of journalists and the public more broadly. Curbing journalists' digital rights means restricting the public's right to know and damaging the freedom of media. Moreover, the importance of Internet freedom is not just limited to the journalists' digital rights (such as online freedom of expression and access to information). Restraining Internet freedom harmfully affect many other rights - in domains like education, the economy, health, women's rights, public engagement in political discourse, freedom of association and peaceful assembly - and reduces the overall quality of life for masses.

This study invokes Pakistan's authorities to respect and recognize the importance of the Internet freedom as a facilitator of not only social, political and economic progress, but also to buttress journalists' digital rights and the freedom of media - especially in digital realm. The author recommends regulatory reforms in order to establish conceptual clarity around the parameters of journalists' digital rights and protection, thereby to foster free and safer journalistic practice in the country. As far as the Internet freedom is concerned, it is important to clarify in detail the rationale for Internet shutdown, blocking of any particular web-site and removal of any online content. And such process should be carried out by an impartial judicial authority or a body that is independent of any political, commercial or other unwarranted influences, so as to ensure that blocking is not used as a means of censorship.

One would recommend safeguarding the Internet freedom, in Pakistan, by removing restrictions on accessing the Internet. Though this could be idealistic to recommend within the context of Pakistan, which restricts fundamental rights based on religious, political and cultural reasons. Nevertheless, it is suggested to develop a culturally customized regulatory framework that respects religion 
and social norms, but it does not abuse journalists' and public's digital rights for political reasons. To sum up, Pakistan's journalists' unions, academia and NGOs should work together to raise their voice for journalists' digital rights by linking it to the freedom of media and other human rights (such as right to privacy); document actively about how the state authorities violate the basic right of free expression and opinion by blocking content on the Internet; and unapologetically denounce every government's action which goes against the basic right of free speech guaranteed to the citizens of Pakistan.

\section{References}

AKHTAR, N. \& PRATT, C. (2017). Pakistani government-news media relationships. Journalism Studies, 18(1), pp.65-85. Available from: https://doi.org/ 10.1080/1461670X.2016.1221738

ASLAM, R. (2015). Pakistan: Media, politics and the threats to journalists in Pakistan. Pacific Journalism Review, 21(1), pp. 177-194.

AZEEM, T. (2019). Pakistan's undeclared censorship. Available from: https:// thediplomat.com/2019/05/pakistans-undeclared-censorship/

BARI, M. (2021). Pakistan journalists face charges for criticizing military. Deutsche Welle, 18th January, 2021. Available from: https://www.dw.com/en/ pakistan-journalists-military-press-freedom/a-56265949

BELSON, D. (2019). Social media crisis drives ongoing decline in global Internet freedom. Available from: https://www.internetsociety.org/blog/2019/11/socialmedia-crisis-drives-ongoing-decline-in-global-internet-freedom/

BENNETT, W. L. \& LIVINGSTON, S. (2018). The disinformation order: Disruptive communication and the decline of democratic institutions. European Journal of Communication, 33(2), pp. 122-139. DOI:10.1177/0267323118760317

BIGO, D. (2014). Security, surveillance and democracy. In: K. Bell, K. Haggerty, \& D. Lyon, The Routledge handbook of surveillance studies, London and New York, Taylor \& Francis Group.

CHABBA, S. (2020). Pakistan's new Internet laws tighten control over social media. Deutsche Welle, 24th February, 2020. Available from: https://www.dw.com/ en/pakistans-new-internet-laws-tighten-control-over-social-media/a-52375508

CHAOCON, M. (2009). A theory of competitive authoritarian institutions and democratic transition. Available from: https://leitner.yale.edu/sites/default/files/ files/resources/papers/mario.pdf

CHAUDRY, S. (2018). Pakistan: Censorship by stealth. New Internationalist, 15th November, 2018. Available from: https://newint.org/features/2018/11/15/ pakistancensorship-stealth 
DICKINSON, R., \& MEMON, B. (2012). Press clubs, the journalistic field and the practice of journalism in Pakistan. Journalism Studies, 13(4), pp. 616-632.

DEIBERT, R., PALFREY, J., ROHOZINSKI, R., \& ZITTRAIN, J. (2011). Access contested: Toward the fourth phase of cyberspace controls. In: R. Deibert, J. Palfrey, R. Rohozinski, \& J. Zittrain, Access contested security, identity, and resistance in Asian cyberspace information revolution and global politics, Cambridge, MA, MIT Press.

DEIBERT, R. \& ROHOZINSKI, R. (2010a). Beyond denial. In: R. Deibert, J. G. Palfrey, R. Rohozinski, \& J. Zittrain, Access controlled: The shaping of power, rights, and rule in cyberspace, Cambridge, MA, MIT Press.

DEIBERT, R. \& ROHOZINSKI, R. (2010b). Control and subversion in Russian cyberspace. In: R. Deibert, J. G. Palfrey, R. Rohozinski, \& J. Zittrain, Access controlled: The shaping of power, rights, and rule in cyberspace, Cambridge, MA, MIT Press.

Digital rights foundation (2020). Sifting truth from lies in the age of fake news. Available from: https://digitalrightsfoundation.pk/wp-content/ uploads/2020/01/Sifting-truth-from-lies-in-the-digital-age-of-fake-news-final.pdf

Digital rights foundation (2018). Content regulation in Pakistan's digital space: June 2018 human rights council report. Available from: https:// digitalrightsfoundation.pk/wpcontent/uploads/2017/12/

DRAGU, T. \& PRZEWORSKI, A. (2019). Preventive repression: Two types of moral hazard. American Political Science Review, 113(1), pp. 77-87.

ELLIS-PETERSEN, H. \& BALOCH, S. (2019). Extreme fear and self-censorship: Media freedom under threat in Pakistan. The Guardian, 5th November, 2019. Available from: https://www.theguardian.com/world/2019/nov/05/extremefear-and-self-censorship-media-in-pakistan-under-attack

Freedom House (2020). Freedom on the Net. Available from: https:// freedomhouse.org/report/freedom-net/2020/pandemics-digital-shadow

GAMBARATO, R. \& ALZAMORA, G. (2018). Exploring transmedia journalism in the digital age. IGI Global.

GUNITSKY, S. (2020). The great online convergence: Authoritarianism comes to democracies. Available from: https://warontherocks.com/2020/02/the-greatonline-convergence-digital-authoritarianism-comes-to-democracies /

HADENIUS, A. \& TEORELL, J. (2007). Pathways from authoritarianism. Journal of Democracy, 18(1), pp. 143-57.

HOWARD, P. N., WOOLLEY, S., \& CALO, R. (2018). Algorithms, bots, and political communication in the US 2016 election: The challenge of automated political communication for election law and administration. Journal of Information Technology and Politics, 15(2), pp. 81-93. DOI: 10.1080/19331681.2018.1448735 
HUSSAIN, S. (2020). Analyzing media-government relations on policy issues in the semi-democratic milieu of Pakistan. Journalism. Available from: https://doi. org/10.1177\%2F1464884920969086

JAHANGIR, R. (2020). Pakistan among worst countries for Internet freedom: Report. Dawn, 6 ${ }^{\text {th }}$ November, 2020. Available from: https://www.dawn.com/ news $/ 1515156$

JAMIL, S. (2015). Journalists' concepts of freedom of expression and press freedom in Pakistan. Journal of Transnational Worlds of Power: Proliferation of Journalism \& Professional Standards, 1(1), pp. 101-132. New Castle, Cambridge Scholars Publishing.

JAMIL, S. (2019). Mobile phone usage and its socio-economic impacts in Pakistan. In: X. Xu, Impacts of mobile use and experience on contemporary society, Hershey, PA, IGI Global.

JAMIL, S. (2020a). Red lines of journalism: Digital surveillance, safety risks and journalists' self-censorship in Pakistan. In: G. Anna, I. Fadnes, \& K. Roy, Journalist safety and self-censorship, London, Routledge.

JAMIL, S. (2020b). Ethnic news media in the digital age: The impact of technological convergence in reshaping journalists' practices in Pakistan. Journal of Multicultural Discourses, 15(2), pp. 219-239.

JAMIL, S. (2020c). Artificial intelligence and journalistic practice: The crossroads of obstacles and opportunities for the Pakistani journalists. Journalism Practice. Available from: https://doi.org/10.1080/17512786.2020.1788412

JAMIL, S. (2020d). A widening digital divide and its implications for democracy and social inequalities in Pakistan. In: M. Ragnedda \& A. Gladkova, Digital inequalities in the global South, London, Palgrave Macmillan.

JAMIL, S. (2020e). Journalism for sustainable development: The imperative of journalists' rights to freedom of expression and access to information for promoting sustainable development in Pakistan. Journal of Applied Journalism and Media Studies, 9(3), pp.271-291. Available from: https://doi.org/10.1386/ajms_00016_1

JAMIL, S. (2021a). The monitored watchdogs: Journalists' surveillance and its repercussions for their professional and personal lives in Pakistan. Journalism Studies. DOI: 10.1080/1461670X.2021.1904272

JAMIL, S. (2021b). Increasing accountability using data journalism: Challenges for the Pakistani journalists. Journalism Practice, 15(1), pp. 19-40. Available from: https://doi.org/10.1080/17512786.2019.1697956

JAMIL, S. \& APPIAH-ADJEI, G. (2019). Journalism in the era of mobile technology: The changing pattern of news production and the thriving culture of fake news in Pakistan and Ghana. World of Media - Journal of Russian Media 
and Journalism Studies, 3, pp. 42-64. Available from: https://doi.org/10.30547/ worldofmedia.3.2019.2

JAMIL, S. \& APPIAH-ADJEI, G. (2020). Battling with infodemic and disinfodemic: The quandary of journalists to report on COVID-19 pandemic in Pakistan. Media Asia, 44(3-4), pp. 88-109. Available from: https://doi.org/10.1080/01296612.2 020.1853393

JAMIL, S., COBAN., B., AATMAN, B., \& APPIAH-ADJEI, G. (2020). The handbook of research on discrimination, gender equality and safety risks in journalism. Pennsylvania, IGI Global.

JAMIL, S. \& MUSCHERT, G. (2020). Risks to journalists' safety and the vulnerability of media freedom in the U.S. In: G. Muschert, K. Budd, M. Christian, \& R. Perucci, Agenda for social justice: Solutions for 2020. Bristol, UK, Policy Press, (Section V).

JILANI, S. (2019). The decline of media freedom in Pakistan - a journalist tells his story. Deutsche Welle, 10th December, 2019. Available from: https://www. dw.com/en/opinion-the-decline-of-media-freedom-in-pakistan-a-journalist-tellshis-story/a-51553931

LASHMAR, P. (2018). Journalistic freedom and the surveillance of journalists post-Snowden. In: S. Eldridge \& B. Franklin, The Routledge handbook of developments in digital journalism studies, Oxford, UK, Taylor and Francis.

LAVRAKAS, P. (2008). Encyclopedia of survey research methods. Sage Publications, Inc.

LEVITSKY, S. \& WAY, L. (2010). Competitive authoritarianism. New York, Cambridge University Press.

LOWENTHAL, T. (2015). Surveillance forces journalists to think and act like spies. Available from: https://cpj.org/2015/04/attacks-on-the-press-surveillanceforces-journalists-to-thinkact-like-spies.php

LYON, D. (2015). Surveillance after Snowden. Cambridge, UK, Polity Press.

MATTHEWS, K. \& TSAGAROULIS, G. (2020). Why Canada must confront the rise of digital authoritarianism? Available from: https://opencanada.org/whycanada-must-confront-the-rise-of-digital-authoritarianism/

MEZZERA, M. \& SIAL, S. (2010). Media governance in Pakistan: A controversial yet essential relationship. Available from: https://www.clingendael.org/sites/ default/files/pdfs/20101109_CRU_publicatie_mmezzera.pdf

MILLS, A. (2019). Now you see me - Now you don't: Journalists' experiences with surveillance. Journalism Practice, 13(6), pp. 690-707.

NADADUR, R. (2007). Self-censorship in the Pakistani print media. South Asian Survey, 14(1), pp. 45-63. Available from: https://doi.org/10.1177\% 2F097152310701400105 
NICOLE, J. (2020). Freedom of the press, fake news, and disinformation. Available from: https://www.uua.org/international/blog/freedom-press-fakenews-disinformation

NITSCHE, L. \& Hairsine, K. (2016). What are digital rights? Deutsche Welle, $9^{\text {th }}$ December, 2016. Available from: https://www.dw.com/en/what-are-digitalrights/a-36703292

Online space for dissent, freedom of expression in Pakistan has shrunk: Report. Dawn, $28^{\text {th }}$ October, 2020. Available from: https://www.dawn.com/news $/ 1587457$

PARK-OZEE, D. (2019). Censorship in Pakistan: Are journalists obligated to speak up? Available from: https://mediaengagement.org/wp-content/ uploads/2019/11/57-Pakistan-Censorship-Case-Study.pdf

PARVEEN, S. \& NAWAZ, M. (2018). Freedom of expression and media censorship in Pakistan: A historical study. Journal of Historical Studies, 4(2), pp. 1-21.

PINTAK, L. \& NAZIR, S. J. (2013). Pakistani journalism: At the crossroads of Muslim identity, national priorities and journalistic culture. Media, Culture \& Society, 35(5), pp. 640-665.

PFUJ says government has a 'hidden agenda to strangulate' freedom of press. The News, 19th January, 2021. Available from: https://www.thenews.com.pk/ latest/776680-pfuj-says-govt-has-a-hidden-agenda-to-strangulate-freedom-of-press

POLIT, D. F. \& BECK, C. T. (2014). Essentials of nursing research: Appraising evidence for nursing practice. Philadelphia, PA, Wolters Kluwer/Lippincott/ Williams \& Wilkins Health.

POLYAKOVA, A. \& MESEROLE, C. (2019). Exporting digital authoritarianism: The Russian and Chinese models. Policy brief, democracy and disorder series. Washington, DC, Brookings, 1-22.

Reporters without borders (2020). 2020 World press freedom index. Available from: https://rsf.org/en/ranking

RITTER, E. \& CONRAD, C. (2016). Preventing and responding to dissent: The observational challenges of explaining strategic repression. American Political Science Review, 110(01), pp. 85-99.

REUTER, O. \& SZAKONYI, D. (2015). Online social media and political awareness in authoritarian regimes. British Journal of Political Science, 45(1), pp. 29-51.

SAEED, A. (2021). 2020 'worst year in Pakistan's history' for press freedom, journalists' union says. Arab News, 1st January, 2021. Available from: https://www. arabnews.pk/node/1785761/pakistan

SARFRAZ, H. (2020). Press freedom declining in Pakistan. Tribune, $3^{\text {rd }}$ May, 2020. Available from: https://tribune.com.pk/story/2212983/press-freedomdeclining-pakistan 
SHAHZAD, A. (2020). New Internet rules to give Pakistan blanket powers of censorship. Reuters, 19 $9^{\text {th }}$ November, 2020. Available from: https://www.reuters. com/article/pakistan-socialmedia-censorship-idINKBN27Z2KF

SHABAZ, A. (2018). Freedom on the Net 2018: The rise of digital authoritarianism. Available from: https://freedomhouse.org/report/freedom-net/2018/rise-digitalauthoritarianism

SIRAJ, S. A. (2009). Critical analysis of press freedom in Pakistan. Journal of Media and Communication Studies, 1(3), pp. 043-047.

STEIN, S. (2013). Obama administration on PRISM program: 'Only non-US persons outside the U.S. are targeted. HuffPost, $7^{\text {th }}$ June, 2013. Available from: https://www.huffpost.com/entry/obama-administration-prism-program_

STRANDBURG, K. J. (2011). Home, home on the web: The fourth amendment and technosocial change. Available from: http://papers.ssrn.com/sol3/papers. cfm?abstract_id $=1808071$

The Economist (2020). Inclusive Internet access. Available from: https:// theinclusiveinternet.eiu.com/

THONRNE, S., STEPHENS, J., \& TRUANT, T. (2016). Building qualitative study design using nursing's disciplinary epistemology. Journal of Advanced Nursing, 72(2), pp. 451-460.

TUFEKCI, Z. (2014). Engineering the public: Big data, surveillance and computational politics. First Monday, 19(7). Available from: http://firstmonday.org/ article/view/4901/4097

WAGNER, B. (2018). Understanding Internet shutdowns: A case study from Pakistan. International Journal of Communication, 12, pp. 3917-3938 